\title{
On the reconstruction of prehistoric social territories: The La Désirade lithic workshops and the distribution of La Désirade chert (French West Indies)
}

\author{
Maaike S. de Waal ${ }^{1,2}$, Sebastiaan Knippenberg ${ }^{1,3}$ \\ 1. Faculty of Archaeology, Leiden University, Einsteinweg 2, 2333 CC, Leiden, Netherlands. \\ Email: de Waal: m.s.de.waal@arch.leidenuniv.nl; Knippenberg: s.knippenberg@archol.nl \\ 2. ARGEOgraph, Netherlands. \\ 3. Archeologisch Onderzoek Leiden BV (Archol), Einsteinweg 2, 2333 CC Leiden, Netherlands.
}

\begin{abstract}
:
The widespread presence of raw materials suitable for the production of stone tools on the southeastern part of La Désirade, a small island east of Guadeloupe (French West Indies), is an interesting feature as these materials cannot be obtained on most of the neighbouring limestone islands. Small amounts of lithic off-site material have been found all over the south-eastern part of La Désirade, indicating that this area was incidentally used for the exploitation of local raw materials for the production of lithic artefacts. Concentrated and repeated activity, related to the exploitation of La Désirade chert, took place at four lithic workshops.

This paper aims to reconstruct social and economic patterns, which may shed a light on prehistoric Amerindian territoriality and mobility, based on the exploitation and distribution of this local raw material. An inventory was made of sites where La Désirade chert was exploited and worked and of sites where this material showed up in the form of worked items.

The La Désirade chert has been found in several prehistoric site assemblages outside La Désirade itself. However, it turns out to have a very restricted distribution, not exceeding $30 \mathrm{~km}$ distances from the raw material occurrences. The authors concluded that exploiting these sources may have been embedded in the general procurement strategy of the seafaring communities involved and that the observed distribution may demonstrate the extent of the territory of closely related communities that exploited a similar catchment area.
\end{abstract}

Keywords: lithic workshops; La Désirade; chert; territories; Caribbean; island archaeology

\section{Introduction}

The study of raw material acquisition, lithic reduction and the distribution and exchange of stone materials and artefacts has received an increasing attention during the past two decades in Caribbean archaeology (Bérard 2004: 159-179; García-Casco et al. 2013; Harlow et al. 2006; Knippenberg 2006; 2011a; Rodríguez Ramos 2001; 2010: 88-144; Queffelec et al. 2018; Schertl et al. 2018). The region's island setting and the inter-island variation in 
geology, making sources often very localized and unique to a single island are characteristics that offer some great potential for this type of research (Knippenberg 2006: 34-92, 151-156; 2011a). This article wants to make a contribution to this line of work by presenting the prehistoric Amerindian lithic workshops at La Désirade, and the characterisation and distribution of the local chert that was worked there. La Désirade is a small Caribbean island, measuring 11 by $2 \mathrm{~km}$, located $12 \mathrm{~km}$ to the east of Guadeloupe (Figure 1). The island is characterised by its remarkable shape. Being a table mountain that rises up from the sea to circa $275 \mathrm{~m}$ height, it looks very different from the surrounding islands.

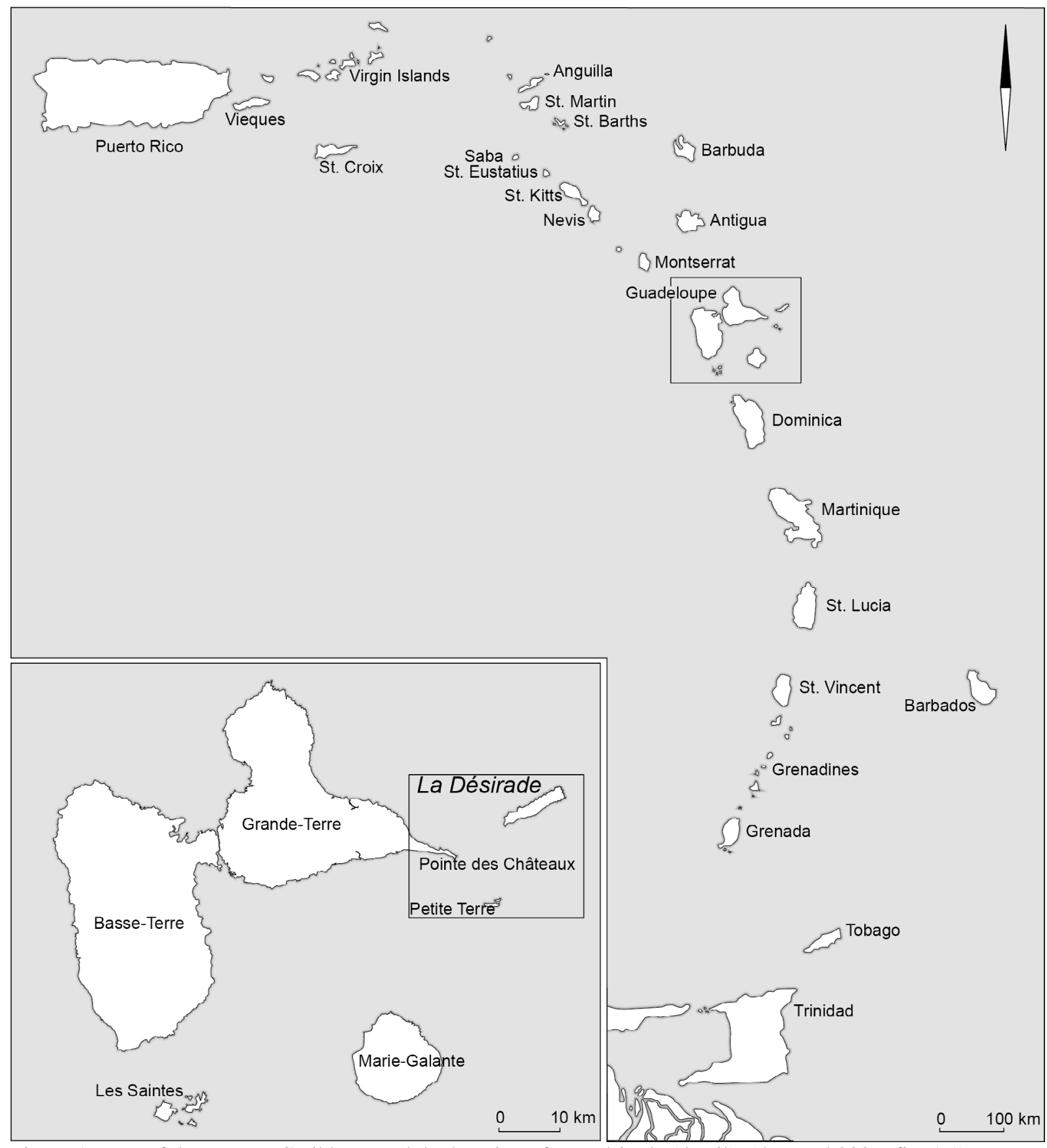

Figure 1. Map of the Eastern Caribbean and the location of La Désirade (detail); (de Waal 2006: fig. 1.1).

The north coast of the island is difficult to reach from the sea, as a result of the steep cliffs and the strong and unpredictable sea currents, whereas the south part is characterised by a gentler slope between the island's central plateau and the southern coastal plain that extends 
along the entire southern coastline (Figure 2). This coastal plain is sheltered from the wind and the reefs along the coastline protect it from strong sea-currents. This is the location where La Désirade’s circa 1600 inhabitants live today (de Waal 2006: 54, 81).

Apart from its shape, La Désirade has another remarkable feature: it has a unique geological composition. Whereas the directly surrounding islands are calcareous, La Désirade, which has a large Neogene limestone cap, is also characterised by its well-exposed magmatic basement, consisting of three different Units dating from the Late Jurassic to the Oligocene-Eocene Epochs (Bouysse et al. 1983; Cordey \& Cornée 2009; Corsini et al. 2011; Mattinson et al. 2008; Montgomery et al. 1992). The oldest northeastern Unit has pillowed metabasalts interbedded with radiolarian chert (Montgomery et al. 1992). This unusual composition, being partially magmatic and partially sedimentary with some rocks having undergone metamorphism, provided a unique possibility for prehistoric inhabitants on Grande-Terre and Guadeloupe's surrounding calcareous islands, an area otherwise devoid of suitable rocks for the manufacture of hard stone tools, to exploit several lithic raw materials, including cherts, magmatic and metamorphic rocks (Knippenberg 2006: 151-222; de Waal 2006: 58-59).

Magmatic rocks occur in the central northern and southern parts as well as at the eastern end of La Désirade. Near Baie Mahault (Figure 2), the magmatic basement is covered by a conglomerate in the deeper parts and by coral fossils in the higher parts. The carbonate sequence on top of the volcanic base appears to consist of calcareous packstone, often containing shell fragments, massive coral boundstones and coral conglomerates (Troelstra \& Beets 2001).

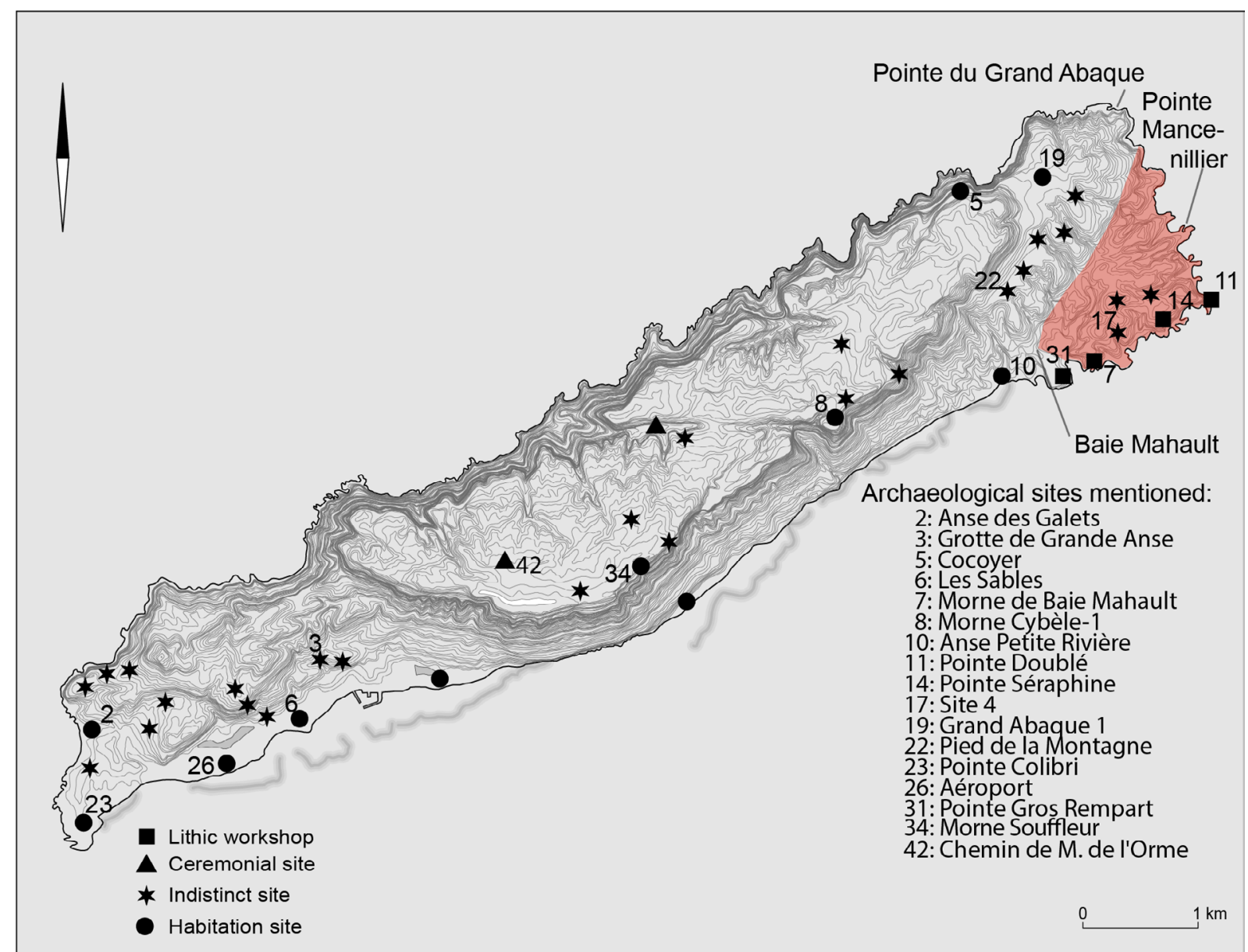

Figure 2. Archaeological sites and topographic locations at La Désirade mentioned in the text (after de Waal 2006: fig. 5.2). The area with red chert outcrops is indicated in red (after Cordey \& Cornée 2009: fig. 3). 
Apart from (meta-)igneous rocks the magmatic basement also contains significant chert beds. These cherts surface within the eastern end of the island, along the southern and eastern shores (Figure 2). Since French archaeologist Pierre Bodu had carried out small-scale archaeological work on La Désirade in the early 1980s, the prehistoric use of these cherts has been acknowledged and the chert's potential as a raw material with regional significance had been hypothesised (Bodu 1984). Due to its low abundance in settlement sites in the region, however, it always remained somewhat under the radar and its actual significance never had been fully attested and further studied in detail. Archaeological work during the past two decades, including a systematic survey and small-scale excavations on the island itself (de Waal 2006: 38-46) as well as the study of a growing number of lithic assemblages from within the larger region (Knippenberg 2006: 93-222; 2009; 2011a; 2011b; 2012; 2016; 2017; 2018), allow for a more detailed regional analysis of this seemingly modest lithic material. This paper therefore focuses on the exploitation and use of La Désirade chert by prehistoric Amerindian groups (who frequented this region roughly between 1500 BCE and CE 1493), in order to identify social and economic territoriality and mobility patterns.

\section{La Désirade chert}

La Désirade is one of the few Lesser Antilles islands that possesses deposits of radiolarian chert (Cordey \& Cornée 2009; Montgomery \& Kerr 2009; see also Knippenberg 2011a). The cherts occur in bedded sequences within pillow basaltic flows, as well as in thin layers in volcaniclastics (Cordey \& Cornée 2009: 401, fig. 4). There are several locations at the eastern end of the island where outcrops of this chert can be found and where it can be easily collected (Figures 2 and 3) (Cordey \& Cornée 2009). Large outcrops occur at the coast between Baie Mahault and Pointe du Grand Abaque, most notably close to Pointe Doublé and Pointe Mancenillier, which is at the approximate middle of the eastern side of the island (Figure 2) (Cordey \& Cornée 2009: 401).

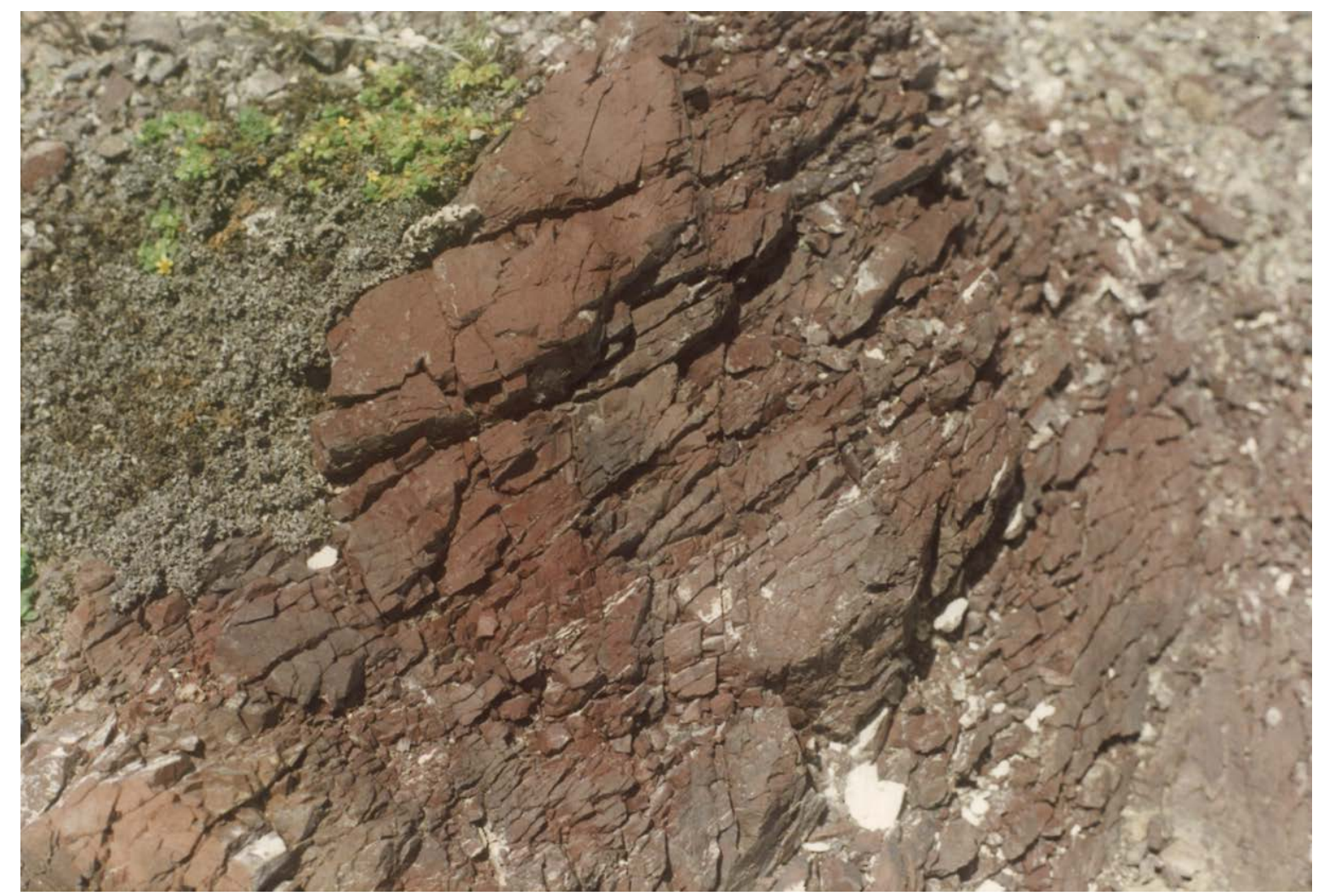

Figure 3. Natural occurrence of red chert at the eastern part of La Désirade (Picture by Maaike de Waal). 
La Désirade chert is a radiolarian chert variety, Late Jurassic in age, making it one of the oldest rocks in the Lesser Antilles (Cordey \& Cornée 2009; Corsini et al. 2011; Lardeaux et al. 2011; Montgomery \& Kerr 2009). It contains Upper Jurassic radiolarian fossils, which can be easily observed by thin-section analysis (Figure 4) (see also Cordey \& Cornée 2009: plates 1-2; Mattinson et al. 2008: fig. 5). In some red cherts in the island radiolarians are absent or rare, but in other locations at La Désirade, cherts with high concentrations of radiolarian fossils do occur (Mattinson et al. 2008: 178; Montgomery \& Kerr 2009: 464). Its formation is considered to be a co-occurrence of "slow radiolarian deposition generating ribbon chert sediments" as well as hydrothermally formed volcanic jaspers (Cordey \& Cornée 2009: 405; Montgomery \& Kerr 2009: 460-3).
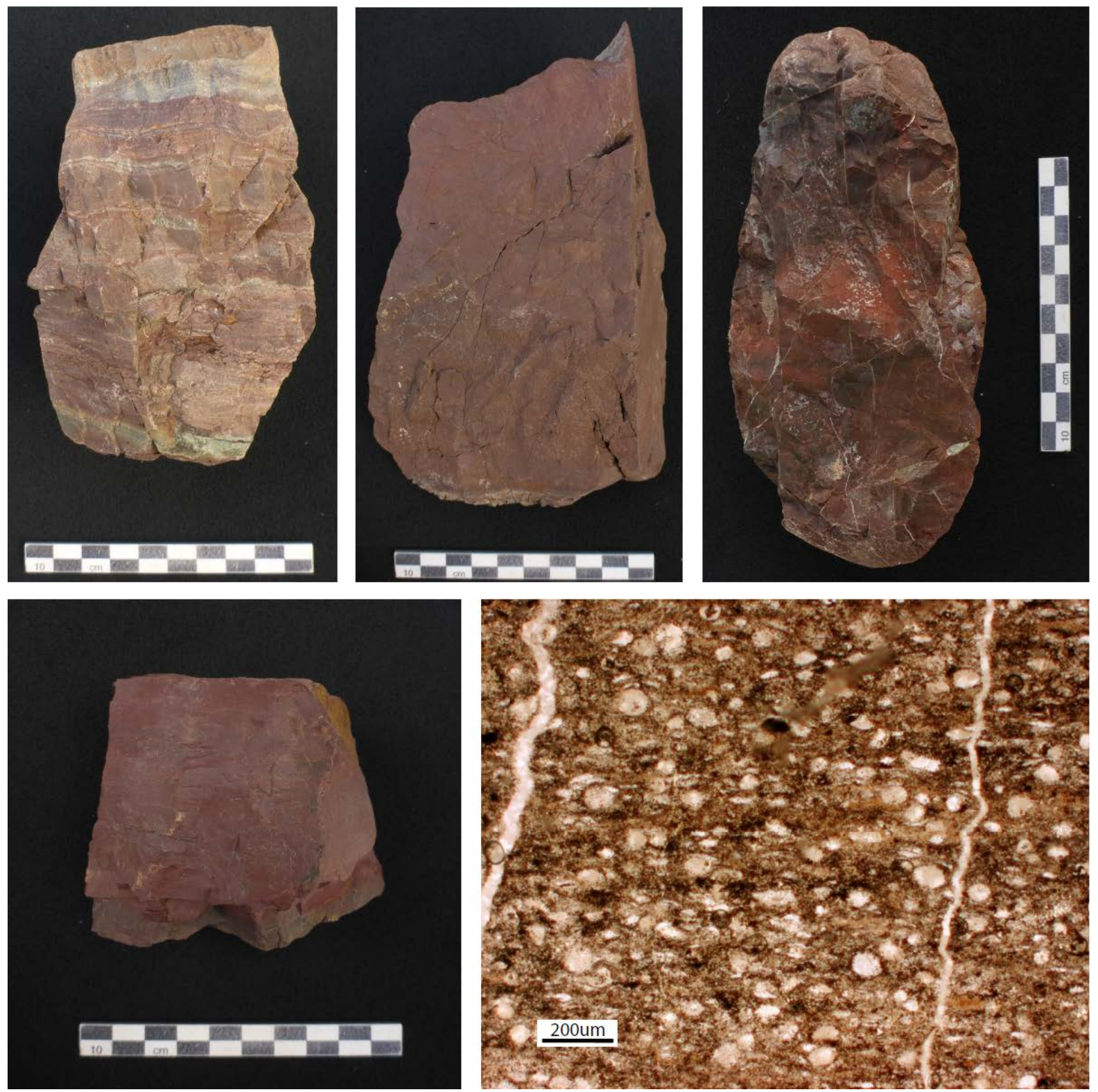

Figure 4. La Désirade red chert. Upper row: three chert samples: a cobble displaying La Désirade grayish, greenish gray, and red chert varieties (left), a more homogeneous middle grained red chert variety (middle), and a more heterogeneous red variety with fractures (right). Lower row: red chert fine grained sample (left) from which thin section (right) has been taken; thin section clearly displays lightly coloured round radiolarian fossils with quartz infillings, darker zones in the matrix represent zones rich in hematite (Pictures by Sebastiaan Knippenberg). 
La Désirade chert is fairly siliceous (69-75\% $\mathrm{SiO}_{2}$ ) (Montgomery \& Kerr 2009: 460). Predominant is a weak red (Munsell Soil Color Charts: 10R 4/2-5/2, 4/4) to dusky red (10R 3/2-3/3) variety, although more grayish and dark greenish gray (10 GY 4/1) cherts also occur, albeit more rarely (Figure 4). The red colour is caused by the presence of submicroscopic hematite, whereas the dark (green) gray varieties have been coloured by manganese oxide (Montgomery \& Kerr 2009: 462).

Macroscopically described the grainsize of the La Désirade chert varies. When compared to the available fine-grained flints and most jaspers in the region, it is coarser and can be described as medium-grained, which gives the rock a sandy feel. From a knapper's point of view, qualitatively it can be considered a relatively poor chert. The material is generally characterised by the many internal fractures and considerable internal variation in grainsize, even within individual pieces of rock. Many of the chert cobbles are rather brittle and easily fall apart when worked. Prehistoric Amerindian inhabitants of the region must have deliberately searched for finest-grained cobbles, selecting materials without internal fractures or without clear bedding, in order to allow shaping and manufacturing of the chert into tools.

Radiolarian cherts are rare among the Lesser Antilles, most of the cherts being nodular flints in limestone, and volcanic jaspers and chalcedonies, and all being of significance to the prehistoric inhabitants of the region (Knippenberg 2006; 2011a). When compared to these, the La Désirade chert most closely resembles red varieties of jasper. Still La Désirade chert can fairly easily be identified and distinguished macroscopically from these jasper varieties (Knippenberg 2011a; 2014). Most typical features are its internal layering, medium grainsize and sandy feel, dull appearance and absence of macro-crystal authigenic quartz crystal inclusions. Also its weak to dusty red colour is different from the brighter red (7.5/10R 4/6$4 / 8$ ) commonly encountered among jasper varieties. The common occurrence of internal fractures also distinguishes it from most jasper rock, although as a result of human selection internal fracturing is less common among the archaeological La Désirade chert material than among naturally occurring chert. Microscopically the presence of radiolarians makes the chert not only distinctive from jasper, but also from chalcedony and flint varieties, that all lack such fossils (Knippenberg 2006: 45-52, 277-292).

\section{The La Désirade lithic workshops}

\subsection{Workshop locations}

Systematic and highly intensive archaeological surface surveys, carried out in 1999, demonstrated the presence of small amounts of lithic off-site material, almost all over the south-eastern part of La Désirade (Figure 2). This suggests that this area was incidentally used for the exploitation of local raw materials for the production of lithic artefacts (de Waal 2006: 99).

At four locations in the southeastern part of La Désirade, de Waal (2006: 99) identified concentrations of worked lithics, indicating that more concentrated and repeated activity took place here. These locations have been interpreted to represent four lithic workshops, with site areas ranging between $3600 \mathrm{~m}^{2}$ and $11,200 \mathrm{~m}^{2}$. The lithic workshops are situated along the coast (Figure 5), in open, slightly hilly terrain. Although the eastern part of La Desirade was probably less barren in prehistoric times, before the introduction of large-scale colonial agriculture and grazing animals (Boudadi-Maligne et al. 2016), nowadays the sites are covered by almost no vegetation. This results in a very good surface visibility, but also in a situation where the sites are prone to erosion (de Waal 2006: 251, 267, 274-275, 305). 


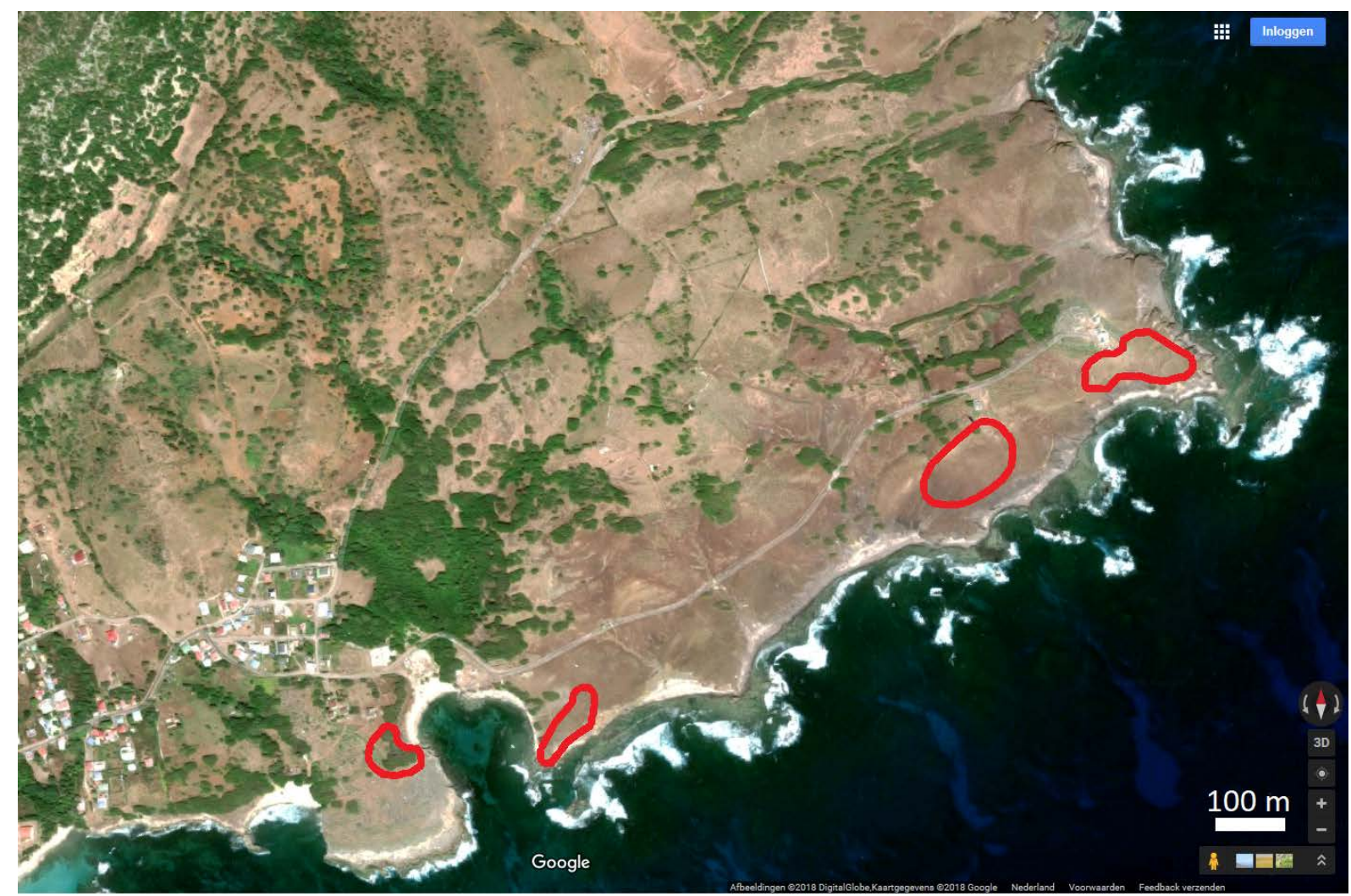

Figure 5. The eastern part of La Désirade with the locations of the lithic workshops. From west to east: Pointe Gros Rempart, Morne de Baie Mahault, Pointe Séraphine and Pointe Doublé (Aerial photograph: google.maps, accessed July 18 2018).

Two of the locations, Pointe Doublé and Morne de Baie Mahault, had already been discovered by Bodu (1984). Two similar sites, Pointe Séraphine and Pointe Gros Rempart, were identified in 1999 by a Leiden University team (de Waal 2006: 50, 274, 304) (Figure 5, Table 1).

Table 1. La Désirade lithic workshops (de Waal 2006; 1984 artefacts from Bodu 1984).

\begin{tabular}{lllll}
\hline Site name & Site ID & Dimensions & $\mathbf{1 9 9 9}$ artefacts & 1984 artefacts \\
\hline Pointe Doublé & $97110-014$ & $100 \times 150 \mathrm{~m}$ & $\mathrm{~N}=26$ & $\mathrm{~N}=149$ \\
Morne de B. Mahault & $97110-011$ & $125 \times 50 \mathrm{~m}$ & $\mathrm{~N}=16$ & $\mathrm{~N}=175$ \\
Pointe Séraphine & $97110-021$ & $170 \times 85 \mathrm{~m}$ & $\mathrm{~N}=59$ & n.a. \\
Pointe Gros Rempart & $97110-038$ & $75 \times 60 \mathrm{~m}$ & $\mathrm{~N}=63$ & n.a. \\
\hline
\end{tabular}

The sites can be easily reached from the sea. Pointe Gros Rempart and Morne de Baie Mahault are situated directly to the west and to the east of a small natural harbour, which would have provided a safe landing place for canoes. From that bay, it is only a 10 to 15 minute walk to the other workshop locations which are at circa 880 and $1200 \mathrm{~m}$ distance. Small amounts of lithic off-site material have been found all over the southern coast, leading from the Morne de Baie Mahault site towards the Pointe Doublé site at the easternmost part of the island, which suggests that the complete southeastern coast was frequented by Amerindian people collecting raw materials for tools. During surface surveys in 1999, no off-site material, in the form of isolated finds, was found in the direct environs of Pointe Gros Rempart (de Waal 2006: 305). This suggests that prehistoric activity was concentrated at this westernmost workshop, resulting in a concentration of artefacts, whereas its direct surroundings show no evidence for being used. 


\subsection{Fieldwork and results}

Related to his 1983 rescue excavation at the settlement site of Anse Petite Rivière at La Désirade (see Figure 2), Bodu also carried out surface surveys of the eastern part of the island. During these surveys he discovered the sites of Pointe Doublé and Morne de Baie Mahault. After having made non-systematic surface collections and detailed analyses of the geological and technological repertoires of the assemblages, he provided a detailed description of the artefacts collected from both sites. These descriptions include information about the origin and quality of the raw materials encountered, as well as a typological and technological characterisation of the collected artefacts (Bodu 1984).

In 1999, two 1 square $m$ test units were excavated at both Pointe Séraphine (Figure 6) and Pointe Gros Rempart in order to be able to characterise the archaeological stratigraphy. Archaeological material was hand-sorted from 2/5 inch dry sieve residues, and $20 \times 20 \mathrm{~cm}$ samples from the north-west corners of the units were wet sieved over $2 \mathrm{~mm}$ screens. These test units indicated that the sites are very shallow and that the archaeological materials are mostly restricted to the surface. At Pointe Gros Rempart, one 19-21 cm thick layer of rather compact, reddish brown (5YR;4/4) loamy sand with a lot of plant roots and some lithic, shell and coral artefacts was discovered. Below this, bedrock was reached (de Waal 2006: fig. A3.32).

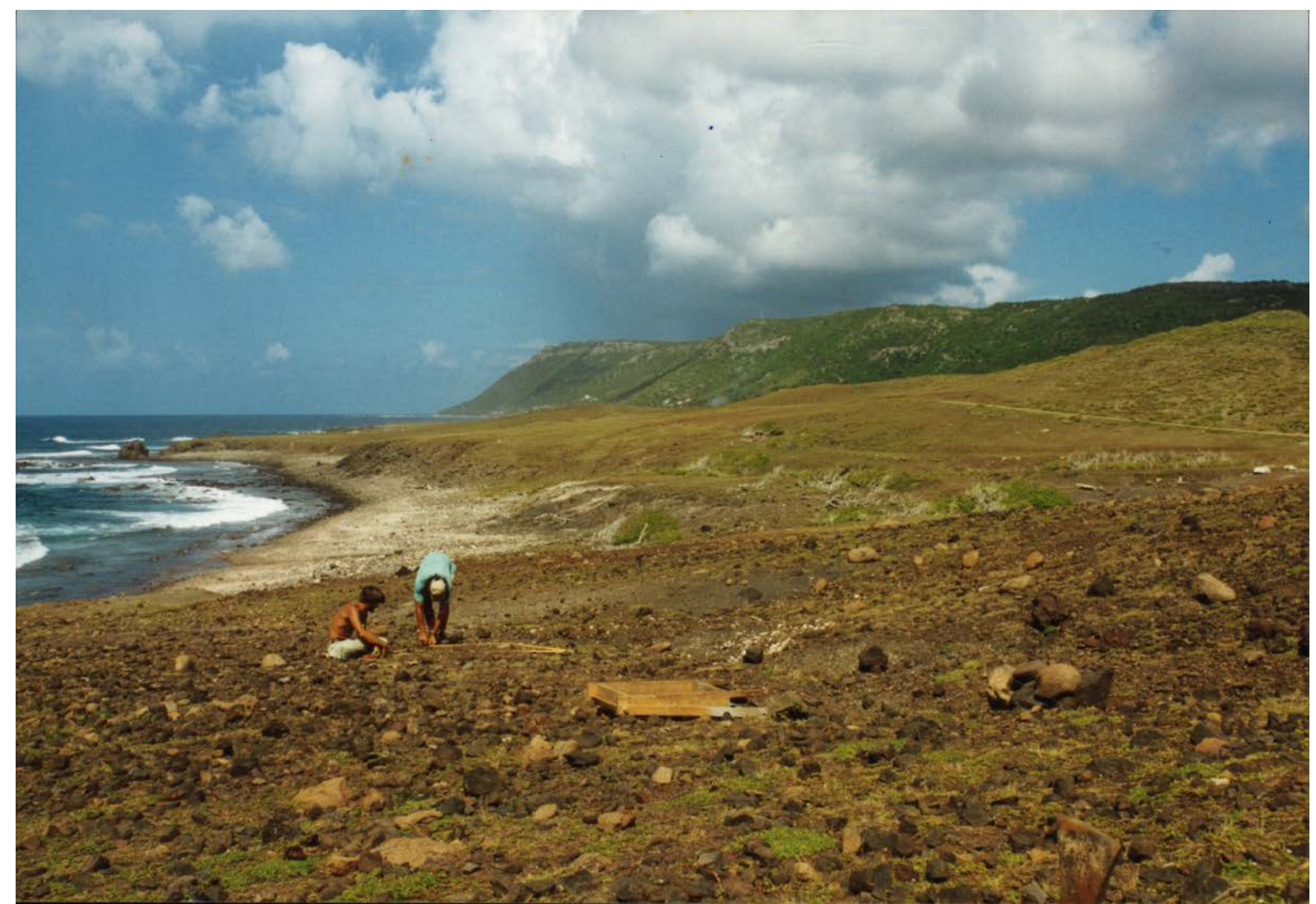

Figure 6. Fieldwork at Pointe Séraphine, La Désirade, in 1999 (Picture by Maaike de Waal).

The Pointe Séraphine site turned out to be even more shallow. Here, the soil consisted of circa $5 \mathrm{~cm}$ of loose, dark brown $(10 \mathrm{YR} ; 3 / 3)$ sandy clay with small stones, containing only two lithic artefacts. Between 5 to $8-14 \mathrm{~cm}$ depth, a very compact, very dark gray $(10 \mathrm{YR} ; 3 / 1)$ sandy clay with lots of small bedrock nodules and without archaeological material was identified. Bedrock was reached between 8-14 cm below the surface (de Waal 2006: fig. A3.22). 
The lithic workshops can be characterised as areas where locally available raw materials were worked. Apart from local chert and igneous rock the sites also yielded varying amounts of non-local rocks and other find categories. Hardly any settlement refuse was found, suggesting long term habitation at the sites had not occurred. Among the non-lithics some weathered shell fragments, including locally available West Indian top shell (Cittarium pica) and queen conch (Lobatus gigas) were observed. A few shell axes and possible gouges with sharpened edges were collected from Pointe Séraphine, Pointe Gros Rempart and Pointe Doublé. Bodu (1984) reported an amethyst bead for Morne de Baie Mahault, but this artefact turned out to be unavailable for analysis. At Pointe Gros Rempart, a few plain pottery sherds and several heavily used passive grinding tool fragments from coral were found as well (de Waal 2006: 304-305). In addition, one prehistoric pottery sherd and faunal remains were discovered in a test unit excavated at this site (Boudadi-Maligne et al. 2016).

It is important to note that chert does not occur naturally at Pointe Gros Rempart (see Figure 2), and, as noted above, no off-site material was found in the immediate surroundings of this location either. The red and dark gray cherts that were observed at this site must have been deliberately brought there, to be subsequently worked. It is not clear why the effort was taken to transport this material to Pointe Gros Rempart instead of working it at locations more to the east where it surfaces naturally. One reason may be the fact that Pointe Gros Rempart is closest to the bay where canoes can easily land. As this site also yielded ceramics, coral grinding tools, shell artefacts and non-local lithics, another explanation could be that Pointe Gros Rempart represents a small campsite, or a special activity site, where local lithics were brought to be worked, instead of exclusively being a lithic workshop, as it was earlier presented by de Waal (2006: 91). Test excavations of a pit cave at Pointe Gros Rempart (Boudadi-Maligne et al. 2016), yielding burnt fish remains, non-local marine shells and a pottery fragment in secondary context, seem to support this view, but leave the need for larger-scale field investigations to better clarify the site function unchanged.

As no features have been found to indicate the presence of huts or other temporary structures, the sites may probably be characterised as open air workshops. This suggestion should be taken with some care however, as only surface surveys and small test excavations have been carried out. Bodu's (1984) observation that a concentration of material was found close to a large rock in the middle of the Pointe Doublé site, which may have provided protection against the wind, and may have functioned as an anvil during the debitage at the same time, seems to confirm an open air character for at least this workshop.

Unfortunately, no absolute dates have been obtained for the four lithic workshops yet. Because of the absence of ceramics, Bodu (1984) had interpreted Pointe Doublé and Morne de Baie Mahault to have been used during the Archaic period (i.e., the period before 500 BCE). However, based on technological characteristics of the materials (basically the absence of blades or any clues for blade manufacture, which are typical for Archaic Age lithic assemblages in this region) Knippenberg roughly placed the sites in the Ceramic Age (500 BCE - CE 1493) (de Waal 2011: 67). Ceramic Age exploitation is further supported by the presence of small amounts of pottery at Pointe Gros Rempart, the calibrated radiocarbon date of AD 299-507 that Boudadi-Maligne et al. (2016) obtained for the prehistoric layer in a pit cave close to this site, and the bead made of amethyst, a semiprecious stone exclusively associated with the early phase of the Early Ceramic Age (circa 500 BCE - CE 400; Cody 1991; Falci et al. 2020; Hofman et al. 2007; Knippenberg 2006, Queffelec et al. 2018), at Morne de Baie Mahault. In addition, the distribution of La Désirade chert over Ceramic Age sites on the directly surrounding islands clearly shows that these workshop sites had been visited during this period (see below). However, as a few Archaic sites have been reported for neighbouring islands, such as Grande-Terre, Guadeloupe (Paulet-Locard \& Stouvenot 2005; Richard 1994), Basse-Terre, Guadeloupe (Stouvenot \& Casagrande 2015) and Marie-Galante 
(Fouéré et al. 2015; Stouvenot et al. 2014), the possibility cannot be excluded that the exploitation of lithic raw materials in La Désirade started already prior to the Ceramic Age.

\subsection{Technological characterisation of the lithic assemblages}

The lithics discovered at the La Désirade workshops generally comprise simple, mostly ad hoc, lithic artefacts such as unmodified pebbles and cobbles, flakes, flake cores, hammerstones and shatter pieces and other waste material of mostly locally available igneous rock and local chert (Tables 2 and 3; see also Table 1 for total counts of collected artefacts).

Table 2. Artefact percentages of the 1999 collections from the La Désirade lithic workshops (after de Waal 2006).

\begin{tabular}{lcccc}
\hline Artefact type & Pointe Doublé & $\begin{array}{c}\text { Morne de } \\
\text { Baie Mahault }\end{array}$ & $\begin{array}{c}\text { Pointe } \\
\text { Séraphine }\end{array}$ & Pointe Gros Rempart \\
\hline Pebble & - & 6,3 & 6,8 & 3,2 \\
Pebble fragment & 26,9 & - & 5,1 & 6,4 \\
Flaked pebble & 11,5 & - & - & - \\
Hammerstone & 7,7 & 12,4 & 3,3 & 4,7 \\
Flake & 30,9 & 50,0 & 37,3 & 61,9 \\
Flake core & 11,5 & 6,3 & 11,9 & 9,5 \\
Shatter piece & 11,5 & 25,0 & 8,5 & 12,8 \\
Unidentified & - & - & - & 1,6 \\
Fragment & - & - & 27,1 & - \\
\hline
\end{tabular}

Table 3. Raw material percentages of the 1999 collections from the La Désirade lithic workshops (after de Waal 2006).

\begin{tabular}{lcccc}
\hline Raw material & $\begin{array}{c}\text { Pointe } \\
\text { Doublé }\end{array}$ & $\begin{array}{c}\text { Morne de } \\
\text { Baie Mahault }\end{array}$ & $\begin{array}{c}\text { Pointe } \\
\text { Séraphine }\end{array}$ & $\begin{array}{c}\text { Pointe Gros } \\
\text { Rempart }\end{array}$ \\
\hline Local igneous rock & 42,3 & 25,0 & 49,2 & 30,2 \\
Local dark gray chert & - & 25,0 & 3,3 & 19,0 \\
Local red chert & 34,6 & 43,7 & 44,1 & 38,1 \\
Non-local red chert & - & - & 1,7 & 4,7 \\
White chert & 7,7 & - & - & 3,2 \\
Light gray chert & 3,9 & - & - & - \\
Light red or light gray chert & 11,5 & - & - & - \\
(Possible) Long Island flint & - & 6,3 & - & 3,2 \\
Unidentified flint & - & - & - & 1,6 \\
Limestone & - & - & 1,7 & - \\
\hline
\end{tabular}

Among the non-local lithics high quality flint from Long Island, which is at circa $125 \mathrm{~km}$ to the northwest of La Désirade, has been found at Morne de Baie Mahault (de Waal 2006: 251; see Knippenberg 2006 for Long Island flint identifications), and one red chert flake core of another variety of rock type, has been discovered at Pointe Séraphine. One of us (SK) identified this latter material to be more flint-like, slightly translucent, chert, and, although it may be local, it differs from what is generally found in the La Désirade workshops (de Waal 2006: 275). Pointe Gros Rempart also yielded a few fragments of cherts, including a red variety, that do not exactly fall in the range of the local chert, having no cleavage and a finer texture. 
Study of the reduction sequence of local chert at the lithic workshop sites on La Désirade is complicated by the small sizes of the lithic assemblages collected from the sites. In addition, the relative abundance of the local red chert within these assemblages is also low (Tables 1 and 3). As result of the poor quality of the artefacts, often being hard to classify and not really photogenic, La Désirade chert objects are usually not recorded in photographs or drawings, which further reduces the possibilities to technologically characterise this material.

Evidence of on-site working of the La Désirade chert is provided by the occurrence of small flake cores, as well as flakes and other forms of debitage (Figure 7). Blocky pieces without clear flaking characteristics, often referred to as shatter, are relatively abundant (10$30 \%$ of all flaked stone). So far very few flake tools have been identified. Bodu (1984) mentions the presence of four $(3,4 \%)$ and six $(3,4 \%)$ flakes with edge damage or retouch for Pointe Doublé and Morne de Baie Mahault respectively. Among the 1999 material no tools have been identified. This may partly be due to the expedient nature of Lesser Antillean Ceramic Age flint and chert working in which intentionally shaping tools and finely working edges hardly played a role (Crock \& Bartone 1998; Knippenberg 2006: 151-222; Rodríguez Ramos 2001: 102-178; Walker 1980: 48-158). Expedient chert tools in general can often only be identified by their actual use-wear traces, which in a lot of cases are very subtle as result of soft materials being worked and because of the short instances of use. Hardly any macroscopically identifiable indications for use have been observed on La Désirade chert. This is probably also the result of the relatively coarse grainsize and the less homogeneous matrix of the material, as compared to many other cherts used in the region, which are likely to blur eventual micro-traces. As a result of this, no use-wear analyses have been carried out on La Désirade chert samples yet.

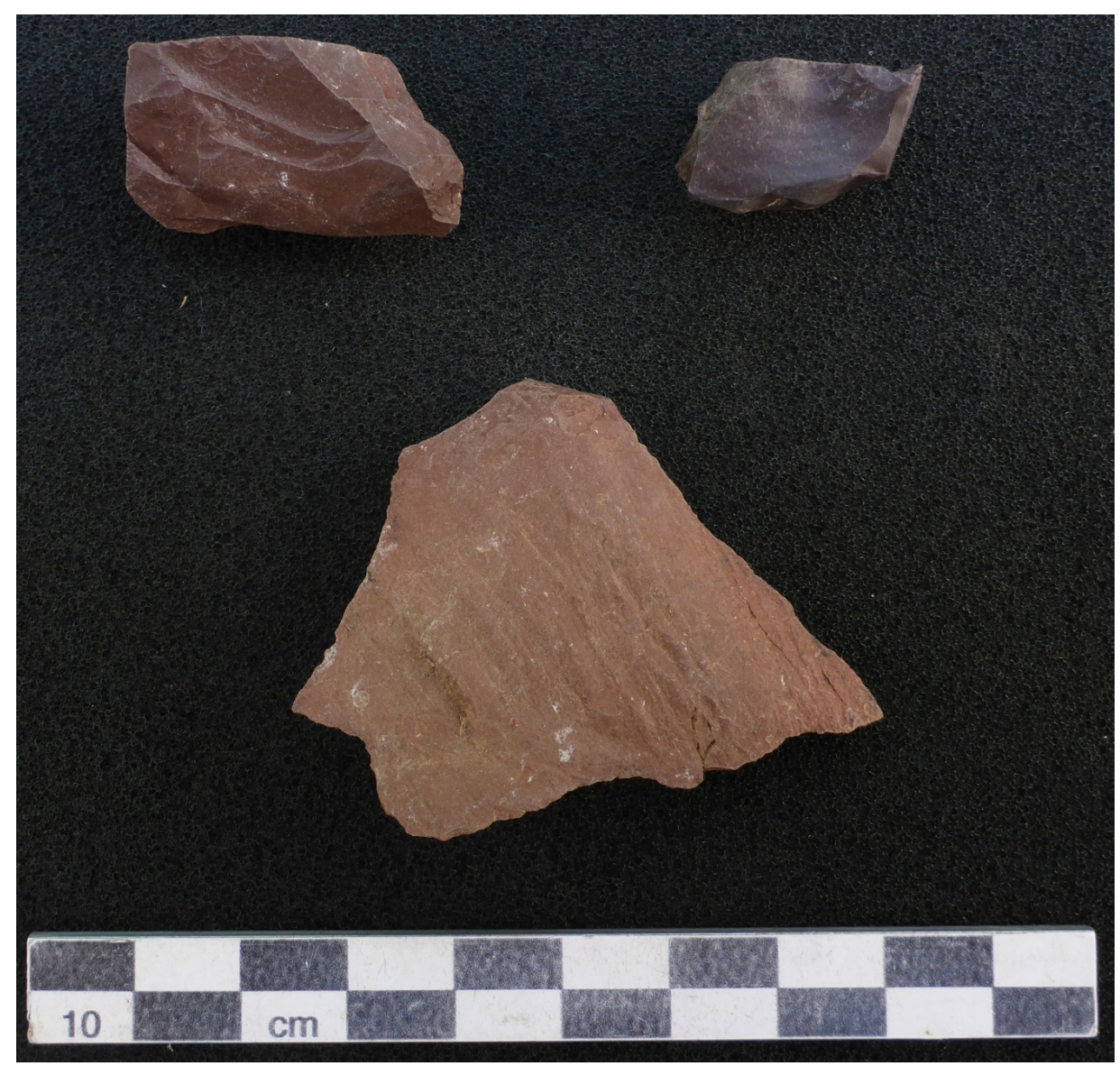

Figure 7. Two small flake cores (top of picture) and a larger flake (bottom of picture) made from La Désirade chert (Picture by Sebastiaan Knippenberg). 
At Morne de Baie Mahault and Pointe Doublé relatively large collections, including 175 and 149 artefacts respectively, were made and studied by Bodu (1984). He concluded that mediocre quality raw material had been reduced following an expedient technology. An unsophisticated direct hard percussion technique had been applied to flake small cobbles in a non-systematic reduction sequence. Its expedient nature is clearly shown by the very small number of flakes showing evidence of deliberate secondary working or fine retouch, and also by the relatively large amount of waste. The smaller samples from the 1999-work, although more limited in the information they provided, do not deviate from this overall description. Although the quality of the material is not very good, the quantity and accessibility apparently made it an attractive raw material to be exploited (Bodu 1984).

Combined with the numerous natural outcrops of the chert itself, these characteristics explain the widespread occurrence of this material at the south-eastern coast of La Désirade. However, the shallow concentrations of lithic material in the lithic workshops appear to indicate that the sites were used only sporadically. Bodu (1984) suggested for example that the assemblage recovered from Pointe Doublé could be the result of several hours' work by a group, or a period of several days of work by an individual. This led De Waal (2006: 99) to conclude that Amerindian people living on La Désirade, or on neighbouring islands, probably used the lithic workshop sites on a very small-scale from time to time.

\section{Micro-regional and regional distributions}

As the lithic workshops have not been accurately dated, they often did not feature in diachronic site maps and presentations of settlement patterns in the Eastern Guadeloupe micro-region (e.g., de Waal 2003; 2011). However, they do seem to play a role which extends beyond the boundaries of La Désirade.

Bodu (1984) suggested that the sites of Morne de Baie Mahault and Pointe Double were used for the manufacture of simple tools by communities living nearby, for example at Anse Petite Rivière on the south coast of the island, which is only at $1 \mathrm{~km}$ walking distance to Morne de Baie Mahault and less than $2 \mathrm{~km}$ as the crow flies to Pointe Doublé. The more recently discovered Pointe Gros Rempart site is even closer-by. Anse Petite Rivière inhabitants could reach this workshop in less than 10 minutes. However, only few local chert artefacts were found at Anse Petite Rivière (Bodu 1984: 2; de Waal 1996: 111-112; 2006: 262-263), suggesting this material was not very important to the inhabitants of this village. The sites of Cocoyer and Grand Abaque 1, both located at the eastern plateaux, represent other prehistoric settlements relatively close to the lithic workshops (see Figure 2). When looking at the other sites at La Désirade, it becomes obvious that La Désirade chert is found in several types of sites, including settlements, ceremonial sites, camp sites and special activity sites, but always in limited quantities (Table 4).

Small quantities of La Désirade chert have also been found in settlements within a restricted region at 20-30 km distance outside La Désirade, such as Anse à la Gourde on nearby Pointe des Châteaux (circa 23 km distance), Est de Mouton de Bas and Pointe Sablé on Petite Terre at circa 20 km distance (Knippenberg 2006: 196; de Waal 2009: 16) and Anse à l'Eau on eastern Grande Terre at circa 30 km distance (Knippenberg 2006: 176). At larger distances from La Désirade, the material has not been identified. Archaeological assemblages from Early and Late Ceramic Age (see section 5 for general chronological assignments) settlement sites at the central and western parts of Grande Terre, at Basse Terre and at MarieGalante, do not contain La Désirade chert (Figure 8) (Knippenberg 2006; 2009; 2012; 2016; 2017; 2018). 
This is remarkable, since other lithic raw materials from La Désirade have had a slightly further distribution. Especially small specific (meta-)igneous rock beach pebbles only to be found on La Désirade and used as fish-net weights and to a minor extent coarse grained (plutonic) igneous rock used for large grinding stones are more commonly found among sites outside La Désirade (Knippenberg 2006; 2018). Inhabitants of islands in the vicinity of La Désirade obviously came to this island to exploit (meta-)igneous raw materials for the manufacture and use of stone artefacts, but these may not always have included chert (see de Waal 2009: 18-19).

Table 4. Numbers (N) and percentages (\%) of La Désirade chert artefacts as part of all flaked stone per site. Artefacts include flakes (F), shatter pieces (S), core artefacts (C), flaked pebbles (FP), flake cores (FC), fragments (FR), or are natural (N); U stands for not specified.

\begin{tabular}{|c|c|c|c|c|c|}
\hline Island and site name & Site type & $\begin{array}{l}\text { Period } \\
\text { (see section 5) }\end{array}$ & $\mathbf{N}$ & $\%$ & $\begin{array}{l}\text { Artefact } \\
\text { type(s) }\end{array}$ \\
\hline \multicolumn{6}{|l|}{ La Désirade } \\
\hline Les Sables & Settlement & $\mathrm{ECB}$ & 2 & 13.3 & For $S$ \\
\hline Anse des Galets & Settlement & LCA & 1 & 33.3 & $S$ \\
\hline Pointe Colibri & Settlement & LCA & 1 & 33.3 & $S$ \\
\hline Aéroport & Settlement & LCA & 1 & 7.1 & C \\
\hline Anse Petite Rivière & Settlement & LCA and LCB & U & $U$ & F, C (Bodu 1984) \\
\hline Morne Cybèle-1 & Settlement & LCB & U & $U$ & F, C (Bodu 1985) \\
\hline Morne Souffleur & Settlement & $\mathrm{LCB}$ & 6 & 46.2 & $1 \mathrm{FP}, 3 \mathrm{~F}, 2 \mathrm{~S}$ \\
\hline Site 4 & Special activity & LCA & 4 & $U$ & Probably N \\
\hline Tropique & Camp site & LCA & 1 & 100.0 & FC \\
\hline Pied de la Montagne & Camp site & Undated & 1 & 33.3 & $\mathrm{~F}$ \\
\hline Voute à Pin & $\begin{array}{l}\text { Ceremonial } \\
\text { cave }\end{array}$ & LCA & 1 & 50.0 & $S$ \\
\hline $\begin{array}{l}\text { Vicinity Ch. de M. De } \\
\text { l'Orme } \\
\text { Guadeloupe (Grande- } \\
\text { Terre) }\end{array}$ & $\begin{array}{l}\text { Ceremonial } \\
\text { depot }\end{array}$ & LCA & 1 & 50.0 & C \\
\hline Anse à la Gourde phase 2 & Settlement & LCA & 1 & 0.6 & FC \\
\hline Anse à la Gourde phase 3 & Settlement & LCA and LCB & 4 & 5.3 & $2 \mathrm{~F}, 1 \mathrm{FC}, 1 \mathrm{~s}$ \\
\hline Anse à l'Eau & Settlement & $\mathrm{ECB}$ & 2 & 1.7 & $1 \mathrm{~F}, 1 \mathrm{FC}$ \\
\hline Morel & Settlement & ECA & 1 & 0.1 & $\mathrm{~N}$ \\
\hline \multicolumn{6}{|l|}{ Petite Terre } \\
\hline Est de Mouton de Bas & Settlement & LCA & 3 & 60.0 & $1 \mathrm{~S}, 1 \mathrm{~F}, 1 \mathrm{FR}$ \\
\hline Pointe Sablé & Settlement & LCA & 1 & 25.0 & $\mathrm{FC}$ \\
\hline
\end{tabular}




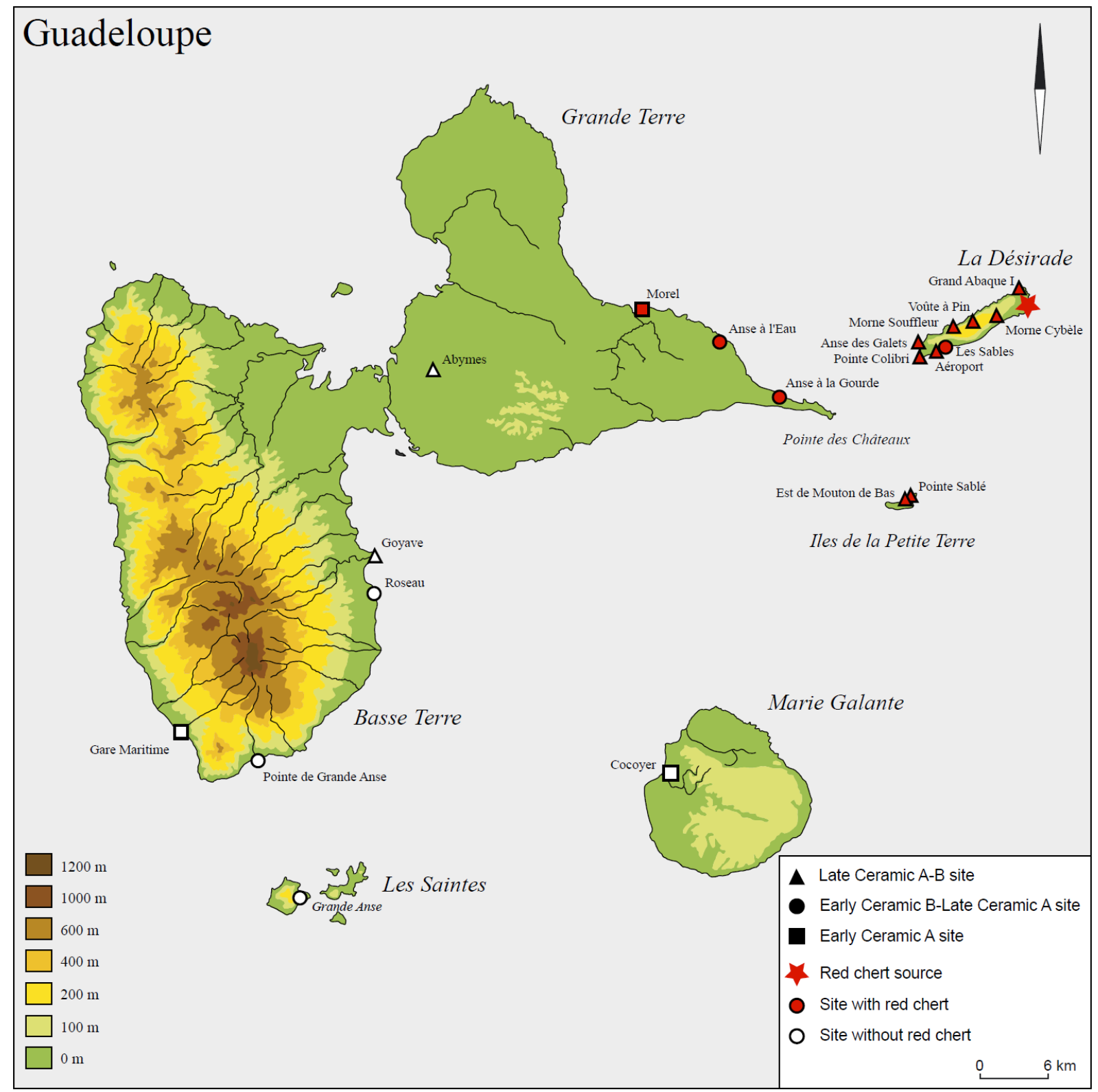

Figure 8. The occurrence of La Désirade chert in archaeological settlement sites.

\section{Distribution and exchange patterns through time}

Although the lithic workshops themselves have not been dated so far, it is possible to provide some deductive dating by looking at dated contexts of La Désirade raw materials that have been discovered in other sites. The earliest evidence for the reduction and use of La Désirade chert was found at Les Sables, at the western part of La Désirade, and Anse à l'Eau, on Guadeloupe (Figure 8). These sites have been dated to the late phase of the Early Ceramic Age (ECB: CE 400 - 600 or 850) (Petersen et al. 2004; see also Knippenberg 2006). During this period, local contact networks were established in the Eastern Guadeloupe micro-region, and apart from locally available limestones, lithic raw materials and finished artefacts from sources on more distant islands including Long Island, Antigua, St. Martin and Martinique, were obtained as well (Knippenberg 2006; de Waal 2006: 105-115, fig. 6.6;). It is interesting to note that non-local flint, for which at least $120 \mathrm{~km}$ had to be travelled, was clearly preferred over the more easily available La Désirade red chert. The higher quality apparently outweighed the distance (Knippenberg 2006; 2011a: 176; de Waal 2006: 111). 
Evidence for the exploitation and use during the earliest phase of the Ceramic Age (ECA: 500 BCE - CE 400) is still inconclusive. The only site that yielded the material is Morel, along Grande Terre's northern coast, but this only consisted of one natural small beach pebble, broken in two fragments (Stevens 2002: 43). As this site also yielded a large amount of small igneous rock waterworn pebbles originating from La Désirade, used as fish-net weights (Knippenberg 2006: 172-174), it is well possible that the red chert pebble had been collected and brought to Morel with a similar purpose in mind, instead of being considered flake tool material. Apparently, the chert sources really started to be exploited at the time of the earliest habitation of La Désirade, at Les Sables.

Most sites where La Désirade chert was discovered date from the early phase of the Late Ceramic Age (LCA: circa CE 600 or 850 - 1200 or 1300). The inhabitants of La Désirade itself were exploiting the chert (as well as other locally available igneous and limestone rocks) most frequently, even though they do not seem to have been using the lithic workshops in an intensive manner (Knippenberg 2006; de Waal 2006: 111). Data from the northeastern Lesser Antilles in general show they focused more strongly on local rocks when compared to the preceding period, even though they still used non-local rocks and continued to participate in (micro-)regional exchange networks (Knippenberg 2006: 268-273). Contact intensified and people inhabiting La Désirade and neighbouring islands participated in exchange networks in which specific high valued materials, such as for example jadeitite, became distributed over longer distances, including almost the entire Caribbean (Knippenberg 2014; Schertl et al. 2018). People living in Pointe des Châteaux continued to prefer qualitatively superior Antigua flint to the easily and abundantly available La Désirade chert, as did the people who started to inhabit Petite Terre from this period onwards (Knippenberg 2006; de Waal 2006: 120, 124).

Late evidence for use of La Désirade chert was found in the sites of Morne Cybèle and Morne Souffleur, on La Désirade, and Anse à la Gourde, on Pointe des Châteaux, dated to the late phase of the Late Ceramic Age (LCB: CE 1200 or 1300 - 1493). During this period, Eastern Guadeloupe inhabitants also obtained non-local rock from Antigua and St. Martin and the high quantity of Antigua flint suggests that this material was still preferred over La Désirade red chert (Knippenberg 2001: 189, 217-219).

Despite the small quantities of La Désirade red chert artefacts found in settlement sites on La Désirade, Grande Terre and Petite Terre, the presence of cores and debitage attest to local on-site reduction of the chert. Following the transport-reduction scheme constructed specifically for Long Island flint use in the region (Knippenberg 2006: 223-242), it can be hypothesised that unworked La Désirade material was brought to settlements to be worked into utensils, rather than pre-working the material at the source locations and transporting reduced cores or tools. Also considering the short distances they had to travel, it is therefore likely that the inhabitants from these sites visited the La Désirade chert sources directly and collected the cobbles themselves. Keeping this in mind and also taking notion of the presence of tools at the workshop sites, the material found at Pointe Gros Rempart, Morne de Baie Mahault, Pointe Séraphine and Pointe Doublé does not seem to represent the debris of preworking material to be brought elsewhere, but to largely represent debris resulting from local, ad hoc use.

\section{Conclusions: Identifying territories within and outside East-Guadeloupe}

The above presented evidence shows that red radiolarian chert from La Désirade was minimally used by people living at this island and at neighbouring islands, all through the Ceramic Age (500 BCE - CE 1493). However La Désirade chert was clearly of limited importance to the communities exploiting the outcrops and surface scatters. All local communities had access to the qualitatively superior Long Island flint, which was the 
predominantly used material, not only on Guadeloupe, La Désirade and Petite Terre, but also within the entire northeastern Lesser Antilles (Knippenberg 2006; 2011a; 2011b; see for other site studies acknowledging the significance of flint from Antigua: Crock \& Bartone 1998; Fouéré 2003; 2006; de Mille 2001; Rodríguez Ramos 2001: 82-85; Walker 1980: 61-65).

Another striking feature of the La Désirade chert is its very restricted distribution. Sites within $30 \mathrm{~km}$ distance from the chert outcrops have yielded the material, but beyond that distance, La Désirade chert has not been found in any significant site assemblage including a fair number of sites within the Guadeloupe archipelago (see Table 4) and beyond (Knippenberg 2006: 151-222). This is remarkable as other materials originating from La Désirade, especially the (meta-)igneous rock beach pebbles, do occur in site assemblages outside the $30 \mathrm{~km}$ distance range (Knippenberg 2018). The $30 \mathrm{~km}$ distance range must have been transferred regularly for these seafaring communities and it can be hypothesised that exploiting these sources was embedded in their regular procurement strategy, that also included sea-trips for fishing and collecting shell-fish as well as assembling other locally nonavailable lithics. As such the distribution signifies the extent of the territory of closely related communities that exploited a similar catchment area.

This corresponds with an evolving pattern in the region starting from circa CE 400, in which control of natural resources had become important, most clearly shown by the restricted number of settlement sites that had been involved in manufacturing cemí three pointer stones from a very distinct conglomerate found on St. Martin (Knippenberg 2006: 254-261). Regarding the radiolarian chert from La Désirade, it may be hypothesised that this catchment area including the lithic sources in some way had been controlled by the communities on La Désirade, Petite Terre and northeastern Guadeloupe. This points to strong social ties between these settlements enabling them to exclude more distant communities from direct access to the chert. Such strong social ties have also been suggested on the basis of strong stylistic similarities in pottery assemblages from this region (de Waal 2006: 121-124, fig. 6.9). This red radiolarian chert is not the only example of very restricted usage of a lithic resource in the region. A similar case may be brought forward for a still poorly studied dusty red jasper variety from Les Saintes, which also has a very localised distribution and use (Knippenberg 2009).

Given the rather poor quality of the material it is puzzling why the chert had been collected and used at all. It can be argued that it represents a relatively hard rock compared to most rock types available in the micro-region. An alternative explanation may relate to its eye-catching red colour, which has proven to be of significance in the Eastern Caribbean. It is known that particular raw materials were not only selected on the basis of their technical or chemical properties, but that they could also be valued "by virtue of ideotechnic considerations such as their colour, lustre, or place of origin” (Rodríguez Ramos 2011: 118; also see Keehnen 2012: 171). Rodríguez Ramos (2010: 19) indicated that "during some periods the color of the raw material used in the production of a celt played as significant a role in its selection as the mechanical properties of the raw material employed in its manufacture".

Among the Antilles it is known that orange carnelian beads have formed a recurrent and important element within the rich bead and pendant industry of the ECA (Bérard 2004: 174177; Crock \& Bartone 1998; Falci et al. 2020; Knippenberg 2006: 167-170; Murphy et al. 2000; Narganes Storde 1995; 1999; Queffelec et al. 2018; Watters \& Scaglion 1994). From natural occurrences within the southern Lesser Antilles with similar abundances of red and yellow jasper, only the red variety shows up at greater distances from their sources (Knippenberg 2011a: 179), suggesting it was a valued item of exchange (Knippenberg 2014). Given the apparent importance that was placed upon these red jasper varieties from the Southern Lesser Antilles, it may be hypothesised that the La Désirade, Petite Terre and 
eastern Guadeloupe communities tried to imitate the red jasper networks of their southern neighbours by exploiting and maybe even controlling their own red chert source. However, it is also possible that the very particular red chert distribution just relates to the rare use of a local and therefore more easily accessible but inferior alternative to high quality flint from Antigua.

Unfortunately, these two hypotheses cannot be sufficiently distinguished for now as result of the small quantities of material that have actually been recovered. Hopefully largescale future work, both outside La Désirade, as well as at the workshops and settlement sites within this island, can overcome this. These viewpoints do, however, highlight the restricted use of a local resource and in that sense, they provide data on microregional inter-community contact, local group territory and, to a lesser degree, group identity. It further shows that despite the apparent insignificance of these local inferior resources they still have a story to tell and therefore need to keep on being investigated.

\section{Acknowledgements}

Many thanks go to the French Ministry of Culture, for financially supporting our fieldwork projects in La Désirade and Guadeloupe, during which many of the data presented in this paper were collected, and to the Netherlands Organization for Scientific Research (NWO; research grant number 250-53-023) for financially supporting travel costs of Sebastiaan Knippenberg. We are also grateful for the useful feedback by the three anonymous reviewers.

\section{References}

Bérard, B. 2004. Les premières occupations agricoles de l'arc antillais, migration et insularité. Le cas de l'occupation saladoïde ancienne de la Martinique. British Archaeological Reports International Series 1299, Paris Monographs in American Archaeology 15, 214 p. (in French) ("The first agricultural occupations within the Antilles Island arc, migration and insularity. The case of the early Saladoid occupation of Martinique").

Bodu, P. 1984, Deux Ateliers de Débitage de Roches Locales en Désirade. (unpublished) Le Moule, Service de l'archéologie, Basse-Terre, Guadeloupe. 32 p. (in French) ("Two Local Rock Workshops at Désirade").

Bodu, P. 1985, Rapport de Fouille de Sauvetage, Morne Cybèle, Le Souffleur, La Désirade. (unpublished), Service de l'archéologie, Basse-Terre, Guadeloupe. 40 p. (in French) ("Rescue excavation report, Morne Cybèle, Le Souffleur, La Désirade").

Boudadi-Maligne, M., Bailon, S., Bochaton, C., Casagrande, F., Grouard, S., Serrand, N. \& Lenoble, A. 2016. Evidence for historical human-induced extinctions of vertebrate species on La Désirade (French West Indies). Quaternary Research, 85(1): 54-65. doi:10.1016/j.yqres.2015.11.001.

Bouysse, P., Schmidt-Effing, R. \& Westercamp, D. 1983, La Désirade Island (Lesser Antilles) revisited: Lower Cretaceous radiolarian cherts and arguments against an ophiolitic origin for the basalt complex. Geology, 11: 244-247. doi:10.1130/00917613(1983)11<244:LDILAR>2.0.CO;2. 
Cody, A.K. 1991, Prehistoric patterns of exchange in the Lesser Antilles: materials, models, preliminary observations. Master's thesis no. 1344090 at San Diego University, San Diego, 422 p.

Cordey, C. \& Cornée, J.-J. 2009, New radiolarian assemblages from La Desirade Island basement complex (Guadeloupe, Lesser Antilles arc) and Caribbean tectonic implications. Bulletin de la Société Géologique de France, 180(5): 399-409. doi:10.2113/gssgfbull.180.5.399.

Corsini, M., Lardeaux, J.M., Verati, C., Voitus, E., \& Balagne, M. 2011, Discovery of Lower Cretaceous synmetamorphic thrust tectonics in French Lesser Antilles (La Désirade Island, Guadeloupe): Implications for Caribbean geodynamics. Tectonics, 30, TC4005. doi:10.1029/2011TC002875.

Crock, J.G., \& Bartone, R.N. 1998, Archaeology of Trants, Montserrat. Part 4. Flaked stone and stone bead industries. Annals of Carnegie Museum, 67: 197-224.

Falci, C.G., Knaf, A.C.S., van Gijn, A., Davies, G.R. \& Hofman, C.L. 2020, Lapidary production in the eastern Caribbean: a typo-technological and microwear study of ornaments from the site of Pearls, Grenada. Archaeological and Anthropological Sciences 12 (53): 1-16. doi:10.1007/s12520-019-01001-4.

Fouéré, P. 2003, Les objets lithiques. Étude techno-archéologique. In: Rivière du Grand Carbet, Capesterre-Belle-Eau (97). Un habitat amérindien multiphasé. (Toledo i Mur, A., Ed.). (Fieldwork report), Unpublished report for the INRAP, on file. Guadeloupe, p. 60-71. (in French) (“The lithic objects. A technological-archaeological study”).

Fouéré, P. 2006, Le matériel lithique. In: Fouille préventive de la Gare Maritime de Basse Terre (Guadeloupe), (Romon, T., Ed.). (Fieldwork report), Unpublished report for the INRAP, on file. Guadeloupe, p. 82-101. (in French) ("The lithic material”).

Fouéré, P., Bailon, S., Bonnissent, D., Chancerel, A., Courtaud, P., Deguilloux, M.-F., Grouard, S., Lenoble, A., Mora, P., Monney, J., Pinçon, K., Queffelec, A. \& Stouvenout, C. 2015, La Grotte de Morne Rita, Capesterre de Marie-Galante (Guadeloupe): Nouvelles Données (oral presentation). Presented at the Congress of the International Association for Caribbean Archaeology (Edition 26), St. Martin, July 2025. (in French) ("The Morne Rita Cave, Capesterre de Marie-Galante (Guadeloupe): New data”).

García-Casco, A., Knippenberg, S., Rodríguez Ramos, R., Harlow, G.E., Hofman, C.H., Pomo, J.C. \& Blanco-Quintero, I.F. 2013, Pre-Columbian jadeitite artifacts from the Golden Rock Site, St. Eustatius, Lesser Antilles, with special reference to jadeitite artifacts from Elliot's, Antigua: implications for potential source regions and longdistance exchange networks in the Greater Caribbean. Journal of Archaeological Science, 40: 3153-3169. doi:10.1016/j.jas.2013.03.025.

Harlow, G.E., Murphy, A.R., Hozjan, D.J., de Mille, C.N. \& Levinson, A.A. 2006, PreColumbian jadeite axes from Antigua, West Indies. Description and possible sources. Canadian Mineralogist, 44: 305-321. doi:10.2113/gscanmin.44.2.305.

Hofman, C.L., Bright, A.J., Boomert, A., \& Knippenberg, S. 2007, Island Rhythms. The web of social relationships and interaction networks in the Lesser Antillean archipelago between 400 B.C. and A.D. 1492. Latin American Antiquity, 18: 243-268. doi:10.2307/25478180. 
Keehnen, F.W.M. 2012, Trinkets (f)or Treasure? The role of European material culture in intercultural contacts in Hispaniola during early colonial times. MA thesis at Leiden University, Leiden, 256 p.

Knippenberg, S. 2001, Artefacts lithiques. In: Guadeloupe, Saint-François, Anse à la Gourde. Fouille programmée pluriannuelle 1995-2000. Rapport de synthèse 2000 (Hofman, C.L., Hoogland M.L.P. \& Delpuech A., Eds.). (Fieldwork report). Unpublished report for Leiden University, not on file. Leiden, p. 175-220. (in French) ("Lithic artefacts").

Knippenberg, S. 2006, Stone artefact production and exchange among the northern Lesser Antilles. Ph.D. thesis at Leiden University. Digital Printing Partners Utrecht B.V., Houten, 382 p.

Knippenberg, S. 2009, Le mobilier lithique amérindien. In: Le site de La Pointe de Grande Anse. Une occupation amérindienne et coloniale dans le sud de Basse-Terre, Commune de Trois-Rivières, Guadeloupe (van den Bel, M., Ed.), (Fieldwork report). Unpublished report for the INRAP, on file. Guadeloupe, p. 61-71. (in French) ("The Amerindian lithic assemblage").

Knippenberg, S. 2011a, Much to choose from. The use and distribution of siliceous stone in the Lesser Antilles. In: Communities in contact. Essays in archaeology, ethnohistory \& ethnography of the Amerindian circum-Caribbean (Hofman, C.L. \& van Duivenbode, A., Eds.). Sidestone Press, Leiden: p. 171-185.

Knippenberg, S. 2011b, Le mobilier lithique. In: Chemin Saint-Louis (van den Bel, M., Serrand, N, Bruxelles, L., Verdin, P., Pagán Jiménez, J., Brancier, J., Cammas, C., Birk, J., Glazer, B. \& Knippenberg, S., Eds.). (Fieldwork report), Unpublished report for the INRAP, on file. Guadeloupe, p. 115 -128. (in French) ("The lithic assemblage”).

Knippenberg, S. 2012, Examen de la matière première lithique du site de la Gare Maritime à Basse Terre. In: Bilan Scientifique de la Région Guadeloupe 2009. Direction Régionale des Affaires Culturelles Guadeloupe, Service Régional de l’Archéologie, Goyave: p. 5253. (in French) ("Analysis of lithic raw material at the Gare Maritime site in Basse Terre”).

Knippenberg, S. 2014, Back to basics. Raw material availability, rock acquisition, and stone tool manufacture and exchange among the Lesser Antilles. Manuscript under revision, Leiden University, 48 p.

Knippenberg, S. 2016, Inventaire lithique. In: CHU Belle-Plaine, Abymes, Guadeloupe. Un site précolombien à l'intérieur des terres (van den Bel, M., Ed.). (Fieldwork report). Unpublished report for the INRAP, on file. Guadeloupe, p. 115-126. (in French) ("Lithic Inventory").

Knippenberg, S. 2017, Inventaire du mobilier lithique. In: STEP de Sainte Claire, Goyave, Guadeloupe. Un morne rouge à double occupation à la Capesterre de la Basse-Terre (van den Bel, M., Ed.). (Fieldwork report). Unpublished report for the INRAP, on file. Guadeloupe, p. 78-92. (in French) ("Inventory of the lithic assemblage”).

Knippenberg, S. 2018, Inventaire du mobilier lithique. In: Parking de Roseau, CapesterreBelle-Eau, Guadeloupe. Sainte-Marie avant l'arrivée de Christophe Colomb (van den Bel, M., Ed.). (Fieldwork report). Unpublished report for the INRAP, on file. Guadeloupe, p. 149-172, 320-330. (in French) ("Inventory of the lithic assemblage").

Lardeaux, J.-M., Corsini, M., Cornée, J.-J., Münch, Ph., Braga, J.C., Cordey, F., Lebrun, J.-F., Léticée, J.L., Marcaillou, B., Melinte-Dobrinescu, M., Moissette, P., Quillévéré, F., 
Randrianasolo, A., Veratiand, C., \& Voitus, E. 2011, La Désirade fieldtrip, Jurassic basement and Pliocene-Early Pleistocene carbonate platform. Field-trip manual La Desirade, March 25 and 26th, 2011. 19th Caribbean Geological Conference, Le Gosier, Guadeloupe, French West Indies, 26 p.

Mattinson, J.M., Pessagno, E.A., Montgomery, H. \& Hopson, C.A. 2008, Late Jurassic age of oceanic basement at La Désirade Island, Lesser Antilles arc. In: Ophiolites, Arcs, and Batholiths: A Tribute to Cliff Hopson (Wright, J.E. \& Shervais, J.W., Eds.). The Geological Society of America, Special Paper 438, Boulder, Colorado: p. 175-190. doi:10.1130/2008.2438(06).

de Mille, Ch., 2001, Lithic Assemblages of four ceramic sites on Antigua. In: Proceedings of the Eighteenth International Congress for Caribbean Archaeology (1): 225-230.

Montgomery, H., Pessagno, E.A. \& Muñoz, I.M. 1992, Jurassic (Tithonian) radiolaria from La Désirade (Lesser Antilles): preliminary paleontological and tectonic implications. Tectonics, 11: 1426-1432. doi:10.1029/92TC01326.

Montgomery, H. \& Kerr, A.C. 2009, Rethinking the origins of the red chert at La Désirade, French West Indies. In: The Origin and Evolution of the Caribbean Plate (James, K.H., Lorente, M.A. \& Pindell, J.L., Eds.), Special Publications 2009, Vol. 328, Geological Society, London: p. 457-467.

Murphy, A.R., Hozjan, A.J., de Mille, C.N., \& Levinson, A.A. 2000, Pre-Columbian gems and ornamental materials from Antigua, West Indies. Gems \& Gemology, 36 (2): 234-245. doi:10.5741/GEMS.36.3.234.

Narganes Storde, Y.M. 1995, La Lapidaria de la Hueca, Vieques, Puerto Rico. In: Proceedings of the Fifteenth International Congress for Caribbean Archaeology: p. 141-151. (in Spanish) ("The lapidary artifacts of la Hueca, Vieques, Puerto Rico).

Narganes Storde, Y.M. 1999, La lapidaria de Sorcé, Vieques e Tecla, Guayanilla, Puerto Rico. In: Proceedings of the Sixteenth International Congress for Caribbean Archaeology (2): 17-26. (in Spanish) ("The lapidary artifacts of Sorcé, Vieques and Tecla, Guayanilla, Puerto Rico).

Paulet-Locard, M.-A. \& Stouvenot, C. 2005, Guadeloupe: Bilan et Orientation de la Recherche Archéologique. In: Bilan Scientifique de la Région Guadeloupe 2005, Direction Régionale des Affaires Culturelles Guadeloupe, Service Régional de l'Archéologie, Goyave, p. 5-7. (in French) ("Evaluation and orientation of the archaeological research").

Petersen, J.B., Hofman, C.L. \& Curet, L.A. 2004, Time and Culture: Chronology and Taxonomy in the Eastern Caribbean and the Guianas. In: Late Ceramic Age Societies in the Eastern Caribbean (Delpuech, A. \& Hofman, C.L., Eds.), BAR international Series 1273, Oxford: p. 17-32.

Queffelec, A., Fouéré, P., Paris, C., Stouvenot, C. \& Bellot-Gurlet, L. 2018, Local production and long-distance procurement of beads and pendants with high mineralogical diversity in an early Saladoid settlement of Guadeloupe (French West Indies). Journal of Archaeological Science: Reports, 21 : p. 175-288. doi:10.1016/j.jasrep.2018.07.011.

Richard G. 1994, Premier Indice d’une Occupation Précéramique en Guadeloupe Continentale. Journal de la Société des Américanistes, 80: p. 241-242. (in French) ("First evidence for preceramic occupation in Guadeloupe"). doi:10.3406/jsa.1994.2768.

Rodríguez Ramos, R. 2001, Lithic reduction trajectories at La Hueca and Punta Candelero sites, Puerto Rico. Master's thesis at the Texas A\&M University, Austin, 215 p. 
Rodríguez Ramos, R. 2010, Rethinking Puerto Rican Precolonial History. The University of Alabama Press, Tuscaloosa, Alabama, 267 p.

Rodríguez Ramos, R. 2011, The circulation of jadeitite across the Caribbeanscape. In: Communities in contact. Essays in archaeology, ethnohistory \& ethnography of the Amerindian circum-Caribbean (Hofman, C.L. \& van Duivenbode, A., Eds.), Sidestone Press, Leiden: p. 117-136.

Schertl, H.-P., Maresch, W.V., Knippenberg, S., Hertwig, A., López Belando, A., Rodríguez Ramos, R., Speich, L. \& Hofman, C.L. 2018, Petrography, mineralogy and geochemistry of jadeite-rich artefacts from the Playa Grande excavation site, northern Hispaniola: evaluation of local provenance from the Río San Juan Complex. In: HPUHP Metamorphism and Tectonic Evolution of Orogenic Belts. (Zhang, L., Zhang, Z., Schertl, H.-P. \& Wei, C., Eds.) Geological Society, London, Special Publications, 474: p. 231-253. doi:10.1144/SP474.3.

Stevens, F. 2002, Morel rocks. A study of lithics of a La Hueca/Cedros style settlement at Morel, Guadeloupe, French West Indies. Master's thesis at the Faculty of Archaeology, Leiden University, Leiden, 86 p.

Stouvenot, C. \& Casagrande, F. 2015. Recherche des Occupations Précolumbiennes dans les Hauteurs de Capesterre-Belle-Eau (Guadeloupe): Résultats Préliminaires (oral presentation). Presented at the Congress of the International Association for Caribbean Archaeology (Edition 26), St. Martin, July 19-25 2015. (in French) ("Investigations of the Pre-Columbian Settlements in the Heights of Capesterre-Belle-Eau (Guadeloupe): preliminary results").

Stouvenot, C., Grouard, S., Bailon, S., Bonnissent, D., Lenoble, A., Serrand, N. \& Sierpe, V. 2014. L'abri sous Roche Cadet 3 (Marie-Galante): Un Gisement à Accumulations de Faune et à Vestiges Archéologiques. In: Archéologie Caraïbe (Bérard, B. \& Losiers, C., Eds.), Sidestone Press, Leiden: p. 77-102. (in French) ("The Roche Cadet 3 shelter (Marie-Galante): A site with accumulations of fauna and archaeological remains”).

Troelstra, S.R. \& Beets, C.J. 2001, Report of the geological fieldwork Guadeloupe, summer 2000. (Fieldwork report). Unpublished report for the Vrije Universiteit Amsterdam, not on file. Amsterdam, $11 \mathrm{p}$.

de Waal, M.S. 1996, The Petite Rivière Excavations, La Désirade, French West Indies. Fieldwork report and subsistence studies for a pre-Columbian site with Late Saladoid and post-Saladoid components. Master's thesis at Leiden University, Leiden, 220 p.

de Waal, M.S. 2003, Pre-Columbian Site Patterns in the Eastern Guadeloupe Area. An Archaeological Survey of La Désirade, Petite Terre and Pointe des Châteaux (19982000). In: Proceedings of the XXth International Congress for Caribbean Archaeology (Tavárez Maria, C. \& García Arévalo, M.A. Eds.). Museo del Hombre Dominicano and Fundación García Arévalo, Santo Domingo: p. 75-84.

de Waal, M.S. 2006, Pre-Columbian Social Organisation and Interaction Interpreted through the Study of Settlement Patterns. An archaeological case-study of the Pointe des Châteaux, La Désirade and Les Îles de la Petite Terre micro-region, Guadeloupe, F.W.I. Ph.D. thesis at Leiden University. Digital Printing Partners Utrecht B.V., Houten, 429 p. 
de Waal, M.S. 2009, Small islands, large settlements: Archaeology at Les Îles de la Petite Terre, Guadeloupe, F.W.I. Caribbean Quarterly, 55(2): 5-22. doi:10.1080/00086495.2009.11829756.

de Waal, M.S. 2011, Pre-Columbian social organisation and interaction in the Eastern part of Guadeloupe. A settlement patterns analysis. In: Proceedings of the XXIIIth International Congress for Caribbean Archaeology (Murphy A.R. \& Rebovich S.A., Eds.), Dockyard Museum, English Harbour, Antigua: p. 51-61.

Walker, J.B. 1980, Analysis and replication of the lithic artifacts from the Sugar Factory Pier site, St. Kitts, West Indies. Master's thesis at the Department of Anthropology, Washington State University, Pullman, 215 p.

Watters, D.R. \& Scaglion, R. 1994, Beads and pendants from Trants, Montserrat: implications for the prehistoric lapidary industry of the Caribbean. Annals of the Carnegie Museum 63: 215-237. 